\title{
Echeandia cholulensis (Asparagaceae), a new species from central Mexico
}

\section{Acta Botanica Mexicana}

\section{Echeandia cholulensis (Asparagaceae), una especie nueva del centro de México}

\author{
Aarón Rodríguez',2 (D), Juan Pablo Ortiz-Brunel,2,3 (iD
}

\begin{abstract}
:
Background and Aims: The genus Echeandia (Asparagaceae) characterizes the Mexican geophyte flora. The group is exclusive of the Americas and includes 85 species. In Mexico, there are 74 species, of which 63 are endemic; however, the species richness is concentrated in the Mexican Transition Zone, including the Transmexican Volcanic Belt (TMVB). Here, we name and describe a new species of Echeandia found along the TMVB in the states of Puebla and Tlaxcala.

Methods: Field work and herbarium revision led us to discover a new species of Echeandia. The morphological description and illustration were based on eight voucher specimens plus living plants from two populations. Moreover, we compared the morphology of the new taxon with that of $E$. michoacensis and E. robusta. Lastly, we assessed its conservation status by calculating its extent of occurrence (EOO) and its area of occupancy (AOO), using the GeoCAT tool and based on the IUCN Red List categories and criteria.

Key results: Echeandia cholulensis is a new species from Mexico. The new taxon includes robust plants characterized by root-thickenings distant from the corm; lanceolate, undulate, and glaucous leaves; ascending flowers with white tepals; clavate and muricate filaments, and free anthers with longitudinal dehiscence. Until now, it is known from three populations in central Mexico in the states of Puebla and Tlaxcala.

Conclusions: Along the TMVB, volcanism has created topographic and climatic variation favoring speciation and persistence. The discovery and morphological description of Echeandia cholulensis exemplifies this observation. Furthermore, botanical exploration and herbaria revisions might discover new species that would increase the great plant diversity of the TMVB.
\end{abstract}

Key words: Mexican Transition Zone, Puebla, Tlaxcala, Transmexican Volcanic Belt.

\section{Resumen:}

Antecedentes y Objetivos: El género Echeandia (Asparagaceae) agrupa geófitas que caracterizan la flora de México. El grupo es endémico de América e incluye 85 especies, 74 de las cuales han sido encontradas en México y 63 son endémicas de este país. Su riqueza se concentra en la Zona de Transición Mexicana, incluido el Eje Volcánico Transmexicano (EVT). En este trabajo, se nombra y se describe a una especie nueva de Echeandia recolectada en el EVT en los estados de Puebla y Tlaxcala.

Métodos: Recolectas en campo y revisión de ejemplares de herbario permitieron el descubrimiento de una especie nueva de Echeandia. Analizamos la morfología de ocho ejemplares de herbario y plantas vivas de dos poblaciones para describir el nuevo taxón y diferenciarlo de $E$. michoacensis y $E$. robusta. Por último, evaluamos su estado de conservación mediante el cálculo de la extensión de ocurrencia (EOO) y el área de ocupación (AOO) con la herramienta GeoCAT y basándonos en las categorías y criterios de la Lista Roja de la IUCN.

Resultados clave: Describimos Echeandia cholulensis como una especie nueva de México. Se caracteriza por desarrollar los engrosamientos de las raíces alejados del cormo. Las hojas son lanceoladas, onduladas y glaucas. Produce flores ascendentes con tépalos blancos, filamentos clavados y muricados y anteras libres con dehiscencia longitudinal. Se conoce de tres poblaciones en el centro de México, en los estados de Puebla y Tlaxcala.

Conclusiones: En el EVT, el volcanismo ha generado variación topográfica y climática que favorece la especiación y persistencia de las plantas. El descubrimiento y descripción morfológica de Echeandia cholulensis ejemplifican lo anterior. La exploración botánica y la revisión de los ejemplares de herbario podrían resultar en el descubrimiento de especies nuevas que aumenten la riqueza florística del EVT.

Palabras clave: Eje Volcánico Transmexicano, Puebla, Tlaxcala, Zona de Transición Mexicana.

${ }^{1}$ Universidad de Guadalajara, Centro Universitario de Ciencias Biológicas y Agropecuarias, Departamento de Botánica y Zoología, Herbario Luz María Villarreal de Puga, camino Ramón Padilla Sánchez 2100, 25510 Zapopan, Jalisco, Mexico.

${ }^{2}$ Universidad de Guadalajara, Centro Universitario de Ciencias Biológicas y Agropecuarias, Departamento de Botánica y Zoología, Laboratorio Nacional de Identificación y Caracterización Vegetal (LaniVeg), Consejo Nacional de Ciencia y Tecnología, camino Ramón Padilla Sánchez 2100, 25510 Zapopan, Jalisco, Mexico.

${ }^{3}$ Author for correspondence: juanpbrunel@gmail.com
Received: June 22, 2021.

Reviewed: September 2, 2021.

Accepted by Marie-Stéphanie Samain: October 11, 2021

Published Online first: November 3, 2021.

Published: Acta Botanica Mexicana 128 (2021).

\section{Acta Botanica Mexicana 128: e1915 | 2021 | htps:}

To cite as: Rodríguez A. and J. P. Ortiz-Brunel. 2021. Echeandia cholulensis (Asparagaceae), a new species from central Mexico. Acta Botanica Mexicana 128: e1915. DOI: https://doi.org/10.21829/ abm128.2021.1915

e-ISSN: 2448-7589 


\section{Introduction}

The main mountain chains of Mexico, including the Transmexican Volcanic Belt (TMVB), form the Mexican Transition Zone (MTZ) (Morrone, 2020). Within the MTZ, orogeny, volcanism and paleoclimatic changes have promoted biological speciation and local survival (Mastretta-Yanes et al., 2015). As a result, angiosperm species richness is concentrated there (Cruz-Cárdenas et al., 2013; Rodríguez et al., 2018; Sosa et al., 2018; Mishler et al., 2020). The Mexican angiosperm flora totals 22,126 species (Villaseñor, 2016), although Joppa et al. (2011) estimated that $15 \%$ remains to be discovered and Espejo Serna (2012) calculated that this percentage is around $30.8 \%$.

The genus Echeandia Ortega (Asparagaceae) characterizes the Mexican geophyte flora (Rzedowski, 2019). It has 85 species, 74 of which grow in Mexico and 63 are endemic to this country (Espejo Serna, 2012; Ortiz-Brunel et al., 2021). The genus ranges from the southwestern United States of America to southern Peru, but several species have narrow geographic ranges. The number of species is increasing since more areas are being explored and detailed analyses are made based on herbarium specimens (Cruden, 1999; López-Ferrari et al., 2002; Rodríguez and Ortiz-Catedral, 2013; Rodríguez and Ortiz-Brunel, 2019). Both field and herbarium work led us to name and describe a new species, which are the objectives of this study.

\section{Materials and Methods}

During a systematic study of Echeandia, we collected tall plants of this genus within the boundaries of the Cholula archaeological site, Puebla. Later, we discovered another population in Tlaxcala. Finally, we found two herbarium specimens (Boege 1478) deposited at the National Herbarium of the Universidad Nacional Autónoma de México (MEXU). These were collected at the Xochitécatl archaeological site in the state of Tlaxcala. All populations were from sites in the Transmexican Volcanic Belt. After the analysis of the vegetative and floral characters of these plants, we concluded that they represented an undescribed species. The morphological description and illustration were based on eight voucher specimens plus living plants from two populations. We followed the terminology described by Moreno (1984). Moreover, we assessed its conservation status by calculating its extent of occurrence (EOO) and its area of occupancy (AOO) using the GeoCAT tool (Bachman et al., 2011) and based on the IUCN Red List Categories and Criteria (IUCN, 2019).

\section{Results}

\section{Taxonomy}

Echeandia cholulensis Aarón Rodr. \& Ortiz-Brunel, sp. nov., Figs. 1, 2.

TYPE: MEXICO. Puebla, municipio San Andrés Cholula, pirámide de Cholula, $2187 \mathrm{~m}, 19^{\circ} 03^{\prime} 27.8^{\prime \prime} \mathrm{N}, 98^{\circ} 18^{\prime} 5.27^{\prime \prime} \mathrm{W}$, 08.VII.2002, A. Rodríguez and L. Ortiz-Catedral 2987 (holotype: IBUG!, isotype: MEXU!).

Plantae robustae; radicum parte incrassata $a b$ cormo 3-4 cm distante; foliis basalibus 6-9, lanceolatis, undulatis, $50-60 \mathrm{~cm}$ longis, 4-5 cm latis, marginibus hyalinis; scapo glabro, 1-1.6 m alto, subtento in dimidio inferiore per bracteam longifoliaceam, ramo 0-1; scapi bracteis $6-8$, ab basin vaginantes; tepalis albis, reflexus; tepalis externis ellipticis, $15-17 \mathrm{~mm}$ longis, 4-5 mm latis; tepalis internis ellipticis, $15-17 \mathrm{~mm}$ longis, 5-7 mm latis; filamentis cylindricis vel clavatis, muricatis, $8 \mathrm{~mm}$ longis; antheris liberis, sagittatis, dorsifixis, $6 \mathrm{~mm}$ longis, lateraliter dehiscentibus; stylo $13 \mathrm{~mm}$ longo; ovario cylindrico, $4 \mathrm{~mm}$ longo, $1.5 \mathrm{~mm}$ lato; capsula elliptica, 9-11 mm longa, 4-5 $\mathrm{mm}$ lata.

Perennial herbs, $100-160 \mathrm{~cm}$ high, including the inflorescence; root-thickenings $3-4 \mathrm{~cm}$ from the corm, 2-4 $\mathrm{cm}$ long; basal leaves 6-9, lanceolate, glaucous, margin hyaline, entire, undulate, $50-60 \mathrm{~cm}$ long, $4-5 \mathrm{~cm}$ wide; inflorescence racemose, rarely 1-branched; peduncle glabrous, ca. $100 \mathrm{~cm}$ long, bracts $6-8$, the lower half of the peduncle enveloped by long-sheathing leafy bracts; raceme ca. $60 \mathrm{~cm}$ long; flowers pedicellate, ascendant, opening in the morning; pedicels green, $10-15 \mathrm{~mm}$ long, articulated the middle; tepals white, reflexed, with 5 green longitudinal nerves; outer tepals elliptic, 15-17 mm long, 4-5 mm wide, acute; inner tepals elliptic, 15-17 mm long, 5-7 mm wide, acute; filaments white, linear, cylindric to clavate, muricate, 


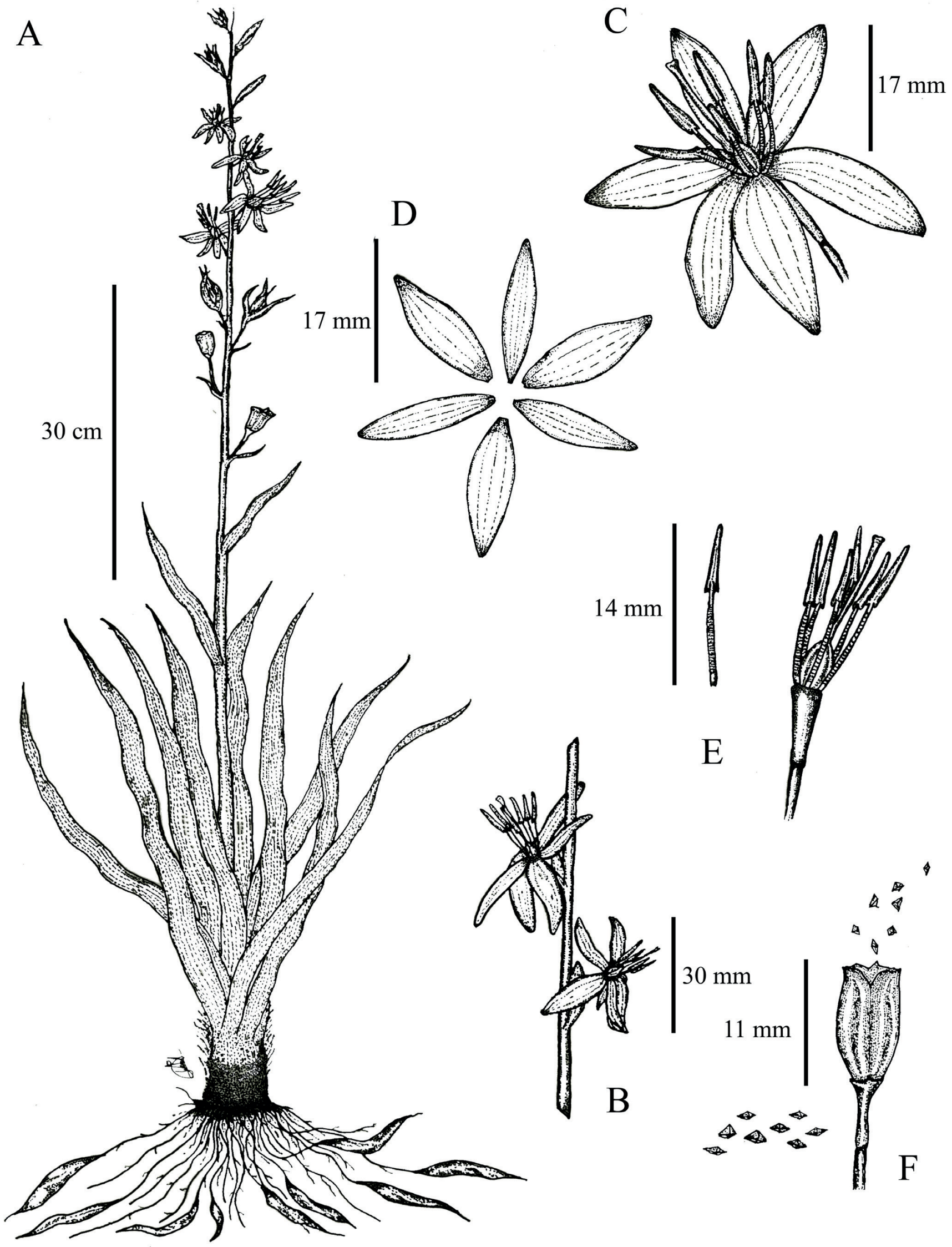

Figure 1: Echeandia cholulensis Aarón Rodr. \& Ortiz-Brunel. A. habit; B. inflorescence detail; C. flower; D. tepals; E. androecium, gynoecium; F. capsule, seeds. Drawn by Juvenal Aragón Parada from the type (A. Rodríguez and L. Ortiz-Catedral 2987). 
ca. $8 \mathrm{~mm}$ long; anthers sagittate, dorsifixed, free, ca. $6 \mathrm{~mm}$ long, dehiscing through longitudinal slits; style white, ca. 13 $\mathrm{mm}$ long, surpassing the anthers by ca. $3 \mathrm{~mm}$; stigma capitate; ovary green, narrowly oblong to narrowly ellipsoid, 3-4 mm long, ca. $1.5 \mathrm{~mm}$ diameter; capsule green, ellipsoid, 9-11 mm long, 4-5 mm wide; seeds deltoid, folded, black, opaque, 1-1.5 mm long, 1-1.5 mm wide.

Etymology: the specific epithet refers to the Cholula archeological site.

Distribution and ecology: Echeandia cholulensis is known from three collections in the states of Puebla and Tlaxcala (Fig. 3). It has been collected in the valleys around the cities of Puebla and Tlaxcala. It grows in open areas with heavy clay soils and gullies with secondary vegetation derived from the pine-oak forest. It has been found between 2200-2400 m elevation. The populations have numerous individuals. The flowers open during the morning and remain so until early afternoon.

Phenology: the flowering and fruiting period extends from July to October.

Conservation status: $\mathrm{EOO}$ and $\mathrm{AOO}$ values were estimated at $42.705 \mathrm{~km}^{2}$ and $12 \mathrm{~km}^{2}$, respectively. Based on the criteria B1a and B2a, established by the IUCN (2019), the new species should be considered as Endangered (EN). Its geographical range lies within the urban areas of Puebla and Tlaxcala. This area is under severe pressure due to the agricultural practices and urban growth. According to the RBG Kew (2016) assessment, both processes represent the first and third causes of plant extinction, respectively. However, Echeandia cholulensis was collected within the boundaries of two archaeological sites: Cholula and Xochitécatl. In Cholula, the population has numerous individuals. As a consequence, both populations are safeguarded since Mexican archaeological sites are protected by federal law.

Additional specimens examined: MEXICO. Tlaxcala, municipio Tepetitla de la Solidaridad, Xochitécatl, 2368 m, 19¹4'44.61"N, 98²1'0.17"W, 11.X.1970, L. W. Boege 1478 (MEXU); cerca de La Corona, $2.3 \mathrm{~km}$ antes de llegar a la caseta de cobro, $2286 \mathrm{~m}, 19^{\circ} 19^{\prime} 5.41^{\prime \prime} \mathrm{N}, 98^{\circ} 24^{\prime} 27.56^{\prime \prime} \mathrm{W}$, 09.IX.2018, G. Munguía-Lino et al. 567 (IBUG, IEB, MEXU, UAMIZ).

\section{Discussion}

Morphologically, Echeandia cholulensis resembles E. michoacensis (Poelln.) Cruden and E. robusta Cruden (Fig. 2). All three species include robust plants with root-thickenings distant from the corm, muricate filaments, and free ascending anthers. Echeandia cholulensis and E. robusta have white tepals, while those of $E$. michoacensis are yellow (Cruden, 1987; 1993). The inflorescence of E. cholulensis is unbranched or produces only one basal branch, in contrast to that of $E$. robusta which branches several times. The flowers of $E$. cholulensis open during the morning and the anthers dehisce by longitudinal slits. Conversely, in E. robusta the anthesis occurs in the afternoon with the release of pollen by apical pores. Echeandia cholulensis occurs in the pine-oak forest or secondary vegetation derived from it, above $2000 \mathrm{~m}$ elevation and along the TMVB in Puebla and Tlaxcala. Collections of E. robusta have been made in southern Jalisco, along the Pacific slopes of the Sierra Madre del Sur. It grows in savannah-like vegetation (Rzedowski and McVaugh, 1966; Rzedowski, 1978), between 500 and 1000 m a.s.l. (Fig. 3).

Cruden (1999) divided Echeandia into subgenera Echeandia and Mscavea Cruden. The former includes plants with flowers opening early in the morning, commonly with elliptic white or yellow tepals, and ellipsoidal fruits. Most species grow above 1500 m elevation. In contrast, plants in the subgenus Mscavea have flowers which open near noon or later, most of them have narrowly elliptical white tepals and globose fruits. These plants grow below 1500 m elevation. According to this, E. cholulensis pertains to $E$. subg. Echeandia.

Villaseñor (2016) listed 22,126 species of angiosperms for Mexico with $49.8 \%$ of them endemic. This number defines Mexico as a hotspot with a diverse flora, ranking it fifth worldwide (RGB Kew, 2016). Based on Sosa et al. (2018), most Mexican plant lineages diversified around 5-20 million years ago, which coincides with the TMVB formation (Ferrari et al., 2012). Consequently, orogeny, volcanism and paleoclimatic changes facilitated the diversifica- 


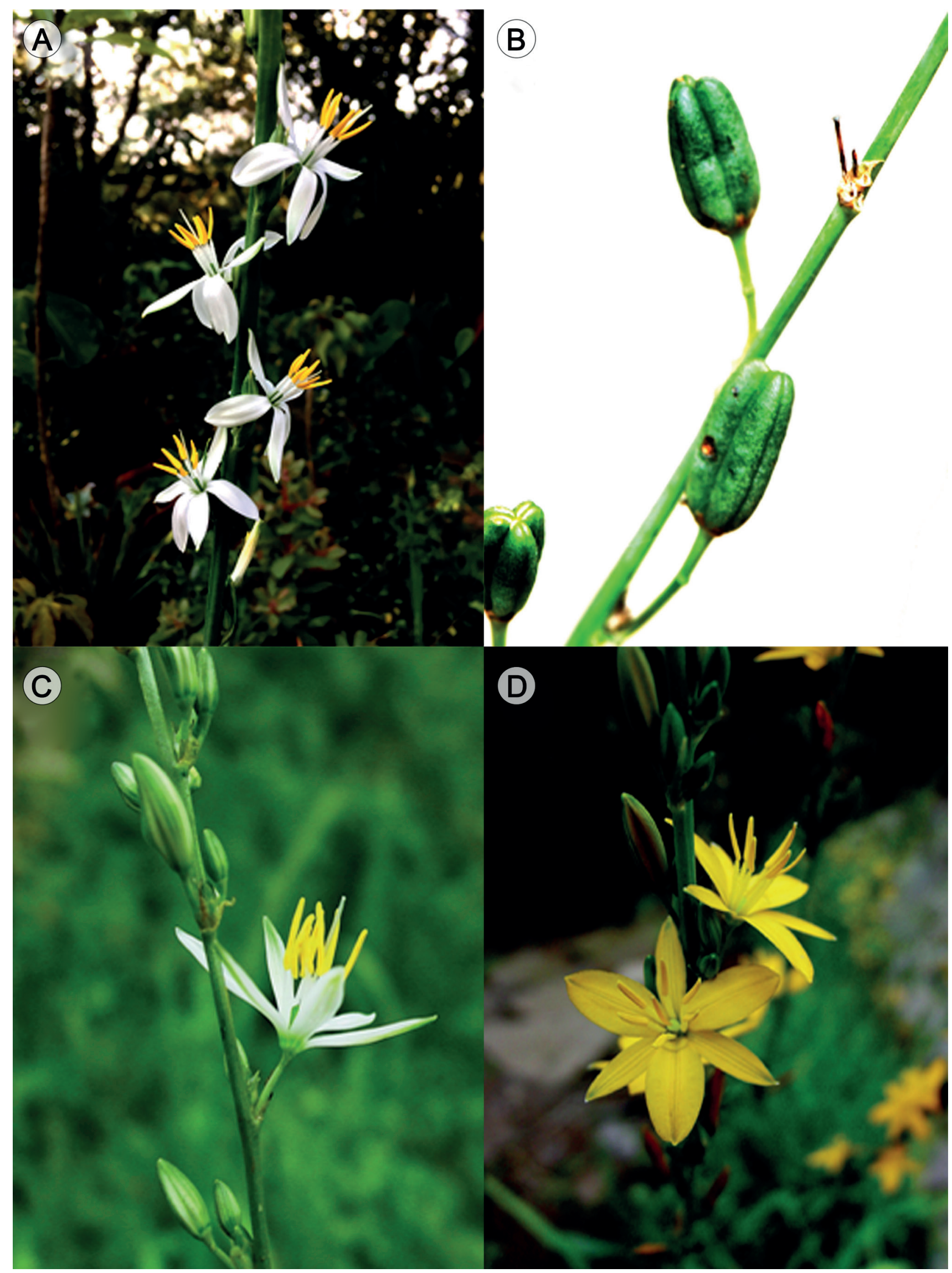

Figure 2: Photos of Echeandia cholulensis Aarón Rodr. \& Ortiz-Brunel and its morphologically related species. A. inflorescence; B. fruits; C. inflorescence of E. robusta Cruden; D. inflorescence of E. michoacensis (Poelln.) Cruden. Photos by Aarón Rodríguez. 


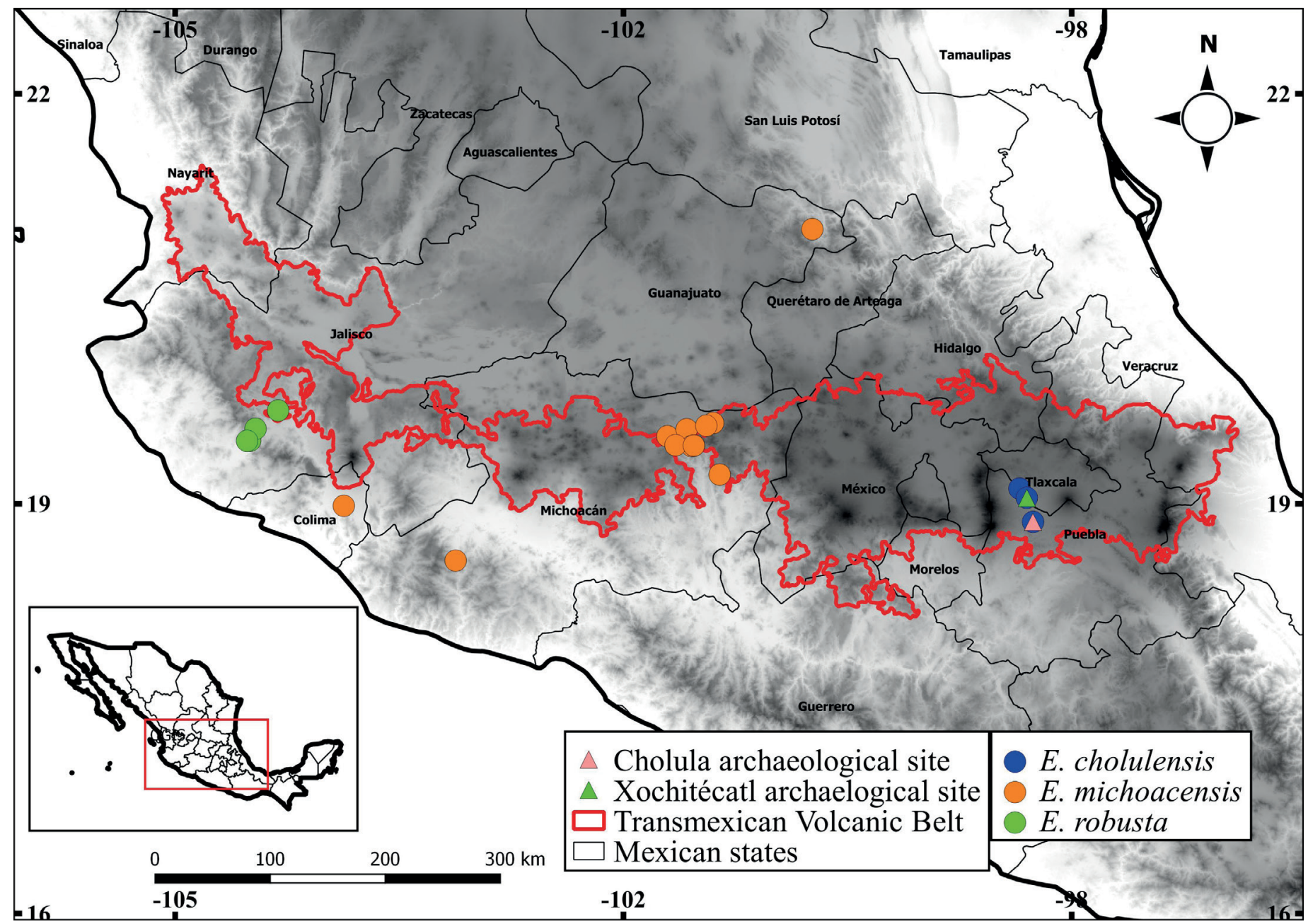

Figure 3: Distribution of Echeandia cholulensis Aarón Rodr. \& Ortiz-Brunel, E. michoacensis (Poelln.) Cruden, and E. robusta Cruden in Mexico.

tion and persistence of the Mexican plant species on the mountainous areas of the country (Mastretta-Yanes et al., 2015; Muellner-Riehl et al., 2019). The diversification of Dioon Lindl. and Quercus L. fits in this scenario (Gutiérrez-Ortega et al., 2018; Hipp et al., 2018).

Yet, several species of plants remain to be discovered, named, and described. At a global scale, Joppa et al. (2011) estimated that this proportion is about 15\%, while Espejo-Serna (2012) calculated that this percentage is around $30.8 \%$ for the Mexican flora. Herbaria hold millions of plant specimens, but Goodwin et al. (2015) assessed that more than $50 \%$ of the tropical collections could be incorrectly identified. Our work highlights the importance of herbaria revision, since botanical exploration provides specimens, but many of these wait inside herbarium cabinets to be reviewed or identified.

\section{Author contributions}

AR led the fieldwork. AR and JPOB reviewed the herbarium specimens, elaborated the species description, and wrote the manuscript. JPOB elaborated the Figures 2 and 3. Both authors reviewed the document and prepared the final version.

\section{Funding}

The University of Guadalajara supported field work and herbaria revision. Part of the financial aid was provided by the Laboratorio Nacional de Identificación y Caracterización Vegetal (LaniVeg), Universidad de Guadalajara and Consejo Nacional de Ciencia y Tecnología (CONACYT).

\section{Acknowledgements}

We thank Luis Ortiz Catedral, Guadalupe Munguía Lino, and Marco Anguiano Constante for their friendly assistan- 
ce in the field during our collecting trips. Jesús Guadalupe González Gallegos helped with the Latin diagnosis, Juvenal Aragón Parada elaborated the illustration of the Figure 1, and Mollie Harker reviewed the manuscript. We thank the suggestions of the anonymous reviewers and the editors.

\section{Literature cited}

Bachman, S., J. Moat, A. W. Hill, J. de la Torre and B. Scott. 2011. Supporting Red List threat assessments with GeoCAT: geospatial conservation assessment tool. ZooKeys 150: 117-126. DOI: https://doi.org/10.3897/zookeys.150.2109

Cruden, R. W. 1987. New species of Echeandia (Liliaceae) from Nueva Galicia. Contributions from the University of Michigan Herbarium 16: 129-133.

Cruden, R. W. 1993. New species of Echeandia (Liliaceae) from Oaxaca, Mexico. Phytologia 74(2): 128-137.

Cruden, R. W. 1999. A new subgenus and fifteen new species of Echeandia (Anthericaceae) from Mexico and the United States. Novon 9(3): 325-338. DOI: https://doi. $\operatorname{org} / 10.2307 / 3391730$

Cruz-Cárdenas, G., J. L. Villaseñor, L. López-Mata and E. Ortiz. 2013. Distribución espacial de la riqueza de especies de plantas vasculares en México. Revista Mexicana de Biodiversidad 84(4): 1189-1199. DOI: https://doi.org/10.7550/rmb.31811

Espejo-Serna, A. 2012. El endemismo en las Liliopsida mexicanas. Acta Botanica Mexicana 100: 195-257. DOI: https://doi. org/10.21829/abm100.2012.36

Ferrari, L., T. Orozco-Esquivel, V. Manea and M. Manea. 2012. The dynamic history of the Trans-Mexican Volcanic Belt and the Mexico subduction zone. Tectonophysics 522-523: 122-149. DOI: https://doi.org/10.1016/j.tecto.2011.09.018

Goodwin, Z. A., D. J. Harris., D. L. Filer, J. R. I. Wood and R. W. Scotland. 2015. Widespread mistaken identity in tropical plant collections. Current Biology 25(22): R1057-R1069. DOI: http://doi.org/10.1016/j.cub.2015.10.002

Gutiérrez-Ortega, J. S., M. M. Salinas-Rodríguez, J. F. Martínez, F. Molina-Freaner, M. A. Pérez-Farrera, A. P. Vovides, Y. Matsuki, Y. Suyama, T. A. Osawa, Y. Watano and T. Kajita. 2018. The phylogeography of the cycad genus Dioon (Zamiaceae) clarifies its Cenozoic expansion and diversification in the Mexican transition zone. Annals of Botany 121(3): 535-548. DOI: https://doi.org/10.1093/aob/mcx165
Hipp, A. L., P. S. Manos, A. González-Rodríguez, M. Hahn, M. Kaproth, J. D. McVay, S. Valencia-Avalos and J. CavenderBares. 2018. Sympatric parallel diversification of major oak clades in the Americas and the origins of Mexican species diversity. New Phytologist 217(1): 439-452. DOI: https://doi. org/10.1111/nph.14773

IUCN. 2019. Guidelines for using the International Union for Conservation of Nature Red List categories and criteria, Version 14. Prepared by the Standards and Petitions Committee. http://www.iucnredlist.org/documents/RedListGuidelines.pdf (consulted April, 2021).

Joppa, L. N., D. L. Roberts, N. Myers and S. L. Pimm. 2011. Biodiversity hotspots house undiscovered plant species. Proceedings of the National Academy of Sciences, USA 108(32): 1317113176. DOI: https://doi.org/10.1073/pnas.1109389108

López-Ferrari, A. R., A. Espejo Serna and J. Ceja Romero. 2002. Una nueva especie de Echeandia (Anthericaceae) de Guerrero, México. Novon 12(1): 77-79. DOI: https://doi. org/10.2307/3393242

Mastretta-Yanes, A., A. Moreno-Letelier, D. Piñero, T. H. Jorgensen and B. C. Emerson. 2015. Biodiversity in the Mexican highlands and the interaction of geology, geography and climate within the Trans-Mexican Volcanic Belt. Journal of Biogeography 42(9): 1586-1600. DOI: https://doi. org/10.1111/jbi.12546

Mishler, B. D., R. Guralnick, P. S. Soltis, S. A. Smith, D. E. Soltis, N. Barve, J. M. Allen and S. W. Laffan. 2020. Spatial phylogenetics of the North American flora. Journal of Systematics and Evolution 58(4): 393-405. DOI: https://doi. org/10.1111/jse.12590

Moreno, N. P. 1984. Glosario botánico ilustrado. Compañía Editorial Continental S. A. de C. V. Cd. Mx., México. 300 pp.

Morrone, J. J. 2020. The Mexican Transition Zone: a natural biogeographic laboratory to study biotic assembly. Springer Nature Switzerland AG. Cham, Switzerland. 191 pp. DOI: https://doi.org/10.1007/978-3-030-47917-6

Muellner-Riehl, A. N., J. Schnitzler, W. D. Kissling, V. Mossbrugger, K. F. Rijsdijk, A. C. Seijmonsbergen, H. Versteegh and A. Favre. 2019. Origins of global mountain plant biodiversity: Testing the 'mountain-geobiodiversity hypothesis'. Journal of Biogeography 46(12): 2826-2838. DOI: https://doi. org/10.1111/jbi.13715 
Ortiz-Brunel, J. P., G. Munguía-Lino, A. Castro-Castro and A. Rodríguez. 2021. Biogeographic analysis of the American genus Echeandia (Agavoideae, Asparagaceae). Revista Mexicana de Biodiversidad 92: e923739. DOI: https://doi. org/10.22201/ib.20078706e.2021.92.3739

RBG Kew. 2016. The state of the world's plants report. Royal Botanic Gardens. Kew, UK. 80 pp.

Rodríguez, A. and L. Ortiz-Catedral. 2013. Echeandia novogaliciana and E. crudeniana (Anthericaceae): two new species from western Mexico. Brittonia 65(3): 347-350. DOI: https://doi. org/10.1007/s12228-012-9293-6

Rodríguez, A. and J. P. Ortiz-Brunel. 2019. Echeandia jaliscensis (Asparagaceae) a new species from Jalisco, Mexico. Phytotaxa 414(1): 29-34.

Rodríguez, A., A. Castro-Castro, G. Vargas-Amado, O. VargasPonce, P. Zamora-Tavares, J. González-Gallegos, P. CarrilloReyes, M. Anguiano-Constante, M. Carrasco-Ortiz, M. García-Martínez, B. Gutiérrez-Rodríguez, J. Aragón-Parada, C. Valdes-Ibarra and G. Munguía-Lino. 2018. Richness, geographic distribution patterns, and areas of endemism of selected angiosperm groups in Mexico. Journal of Systematics and Evolution 56(5): 537-549. DOI: https://doi. org/10.1111/jse.12457

Rzedowski, J. 1978. Vegetación de México. Limusa. México, D.F., México. 432 pp.

Rzedowski, J. 2019. Los géneros de fanerógamas que, sin ser exclusivos de México, dan carácter a su flora. Revista Mexicana de Biodiversidad 90: e902946. DOI: https://doi. org/10.22201/ib.20078706e.2019.90.2946

Rzedowski, J. and R. McVaugh. 1966. La vegetación de Nueva Galicia. Contributions from the University of Michigan Herbarium 9: 1-123.

Sosa, V., A. De Nova and M. Vásquez-Cruz. 2018. Evolutionary history of the flora of Mexico: dry forests cradles and museums of endemism. Journal of Systematics and Evolution 56(5): 523-536. DOI: https://doi.org/10.1111/ jse.12416

Villaseñor, J. 2016. Checklist of the native vascular plants of Mexico. Revista Mexicana de Biodiversidad 87(3): 559-918. DOI: http://doi.org/10.1016/j.rmb.2016.06.017 